IRA-International Journal of Applied Sciences ISSN 2455-4499; Vol.04, Issue 01 (2016)

Institute of Research Advances

http://research-advances.org/index.php/IRAJAS

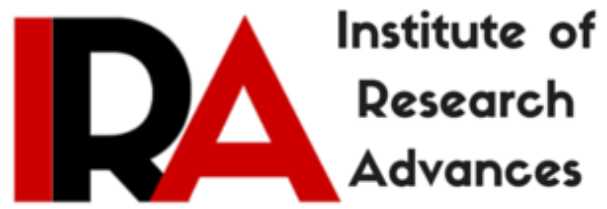

\title{
Use of Models as Non-destructive Method for Leaf Area Estimation in Horticultural Crops
}

\author{
${ }^{1}$ F. A. Khan, ${ }^{2}$ F. A. Banday, ${ }^{3}$ S. Narayan, ${ }^{4}$ F. U. Khan $\&{ }^{5}$ S. A. Bhat \\ Sher-e-Kashmir University of Agricultural Sciences and Technology of Kashmir, \\ Shalimar, Distt. - Srinagar (J\&K), PIN - 190025, India.
}

DOI: http://dx.doi.org/10.21013/jas.v4.n1.p19

\section{How to cite this paper:}

Khan, F., Banday, F., Narayan, S., Khan, F., \& Bhat, S. (2016). Use of Models as Non-destructive Method for Leaf Area Estimation in Horticultural Crops. IRAInternational Journal of Applied Sciences (ISSN 2455-4499), 4(1). doi:http://dx.doi.org/10.21013/jas.v4.n1.p19

(C) Institute of Research Advances

\section{(cc) BY-NC}

This works is licensed under a Creative Commons Attribution-Non Commercial 4.0 International License subject to proper citation to the publication source of the work.

Disclaimer: The scholarly papers as reviewed and published by the Institute of Research Advances (IRA) are the views and opinions of their respective authors and are not the views or opinions of the IRA. The IRA disclaims of any harm or loss caused due to the published content to any party. 


\section{ABSTRACT}

Leaf area estimation is an important biometrical trait for evaluating leaf development and plant growth analysis in field study of horticultural as well as other species of crop plants. These measurements can be made either destructively and/or non-destructively by using a variety of sensitive instruments as well as models of leaf area estimation. Easy, accurate, cost-effective, and nondestructive methods of leaf area estimation are useful tool in physiological studies related to plant growth and development. The use of regression equations is a nondestructive, simple, quick, accurate, reliable and not expensive method of leaf area estimation. The usual procedure of this method involves measuring length $(L)$, breadth (W) and/or dry mass $(M)$ of a sample of leaves and then calculating the several possible regression coefficients or leaf factors to estimate the area of subsequent leaf samples. Computer programs such as Excel, SAS and SPSS may be used in this process. The paper thrashed out several leaf area estimation models of horticultural crops from the available literature and synthesized in tabular form for the use of researchers. Article also offered some advantages and disadvantages of leaf area estimation models used for analyzing the plant growth and development.

\section{INTRODUCTION}

Crop growth, productivity and quality are directly related to leaf area (LA) as leaves constitute the most important aerial organ of the plant, playing a major role in the photosynthetic assimilation by means of the light absorbing pigments (e.g., chlorophyll and carotenoids), which they possess in abundance. Hence, the total leaf area, which in the majority of cases has a direct bearing on the amount of chlorophyll, is an important parameter for assessing the ability of the plant to synthesize its dry matter (Prasada Rao et al., 1978). In addition, leaf area development strongly influences water and nutrient use of the horticultural crop plants and thus important for cultural management practices such as irrigation, fertilization, etc. It is also needed for evaluation of training and pruning systems and estimation of pest population densities in horticultural crops (Lang, 2005a; Anderson et al., 1999; Sepulveda and Kliewer, 1983; Elsner and Jubb, 1988; Lang, 2000b). A large number of methods, either destructive or not, have been developed to measure leaf area. However, measuring the surface area of a large number of leaves, especially in the field, can be costly, time consuming, laborious and usually destructive (Beerling and Fry, 1990). Many methods like tracing, blueprinting, photographing, or using a conventional planimeter, require the excision of leaves from the plants. It is therefore, not possible to make successive measurements of the same leaf. Also, the plant canopy is damaged, which might cause problems to other measurements or experiments (Lu et al., 2004). Non-destructive methods, which do not require the leaves to be detached, are useful because they allow measurements to be repeated during the plant's growth period, and reduce the variability associated with destructive sampling procedures (Silva et al., 2005; Pandey and Singh 2011). Instruments and laser optic apparatuses have been developed for quick, accurate, and non-destructive measurement of leaf area (Daughtry 1990; Fladung and Ritter, 1991; Mori et al., 1991; Smith et al., 1991; Blanke, 1995; Ebert, 1995; Beverly and van Lersel, 1998; Igathinathane et al., 2006). However, these devices are somewhat expensive, time-consuming and complex (Manivel and Weaver, 1974; Robbins and Pharr, 1987) for basic and simple studies. A modelling approach involving linear relationships between LA and one or more dimensions of the leaf is an inexpensive, rapid, reliable and a nondestructive alternative for accurately measuring LA (Williams and Martinson, 2003; Lu et al., 2004). Thus for many fruit (Kobayashi, 1988; Potdar and Pawar, 1991; Uzun and Çelik, 1999; Campostrini and Yamanishi, 2001; Williams and Martinson, 2003; Demirsoy et al., 2004; Demirsoy et al., 2005; Wu et al., 2010; Moghaddam, 2014), vegetables (Chien and Lin. 2002; Blanco and Folegatti, 2005; Carmassi et al., 2007; Olfati et al., 2010; Cemek et al., 2011; Hinnah et al., 2014; Tanko and Hassan, 2016), ornamental (Pereyra et al., 1982; Barbieri et al., 1994; Pinto et al., 2004; Carmassi et al., 2007; Fascella et al., 2013) and medicinal (Cirak et al., 2005; Zenginbal et al., 2006; Antunes, et al., 2008; Odabas et al., 2009; Dheebakaran and Jagannathan, 2009) plants non-destructive and easily applied models for LA estimation have been developed based on simple measurements of leaf length, width, and dry mass. This indirect non-destructive method can provide accurate leaf area estimates in situ. The 
objective of this article was to offer handy simple, accurate, non-destructive and time saving leaf area prediction models for various crop species to be used by the researchers working in the field of horticultural sciences.

\section{MATERIALS AND METHODS}

In general, the development of an estimation model of leaf area requires the measurement of the actual area of each leaf and, often, multiple regressions with length and /or width, etc. Common parameters for prediction equations are leaf length, leaf width, leaf dry mass, petiole length, or some combination of these variables (Gamiely et al., 199; Pandey and Singh, 2011; Rouphael et al, 2010a; Pandey and Singh, 2011). Many studies have been carried out with linear leaf measurements that are highly correlated with leaf area in fruits (Fallovo et al., 2008; Demirsoy, 2009), vegetables (Hinnah et al., 2014; Tanko and Hassan, 2016), ornamentals (Barbieri et al., 1994; Fascella et al., 2013) and medicinal plants (Kumar, 2009; Zhang and Liu, 2010; ). Computer programs such as Excel, SAS and SPSS may be used in this process. For example, for a typical method, each leaf should be placed on a sheet of paper and be photocopied. Then, to measure the actual leaf area, a digital leaf area meter or any suitable tool may be used. The leaf width (W) and length (L) of the leaves sampled can be measured by a simple ruler. After this, regression analysis of the data may be performed separately for each genotype, species or cultivar. The analysis can be conducted with various subsets of the independent variables; for instance, leaf length, leaf width, "leaf length' $\left(\mathrm{L}^{2}\right)$, 'leaf width" $\left(\mathrm{W}^{2}\right)$ and the $\left[\mathrm{L}^{2} / \mathrm{W}^{2}\right]$ ratio to develop the best model for predicting leaf area. Regression analyses should be carried out until the deviation sum of squares is minimized. To choose the best model, standard error, coefficient of correlation $\left(r^{2}\right)$, probability and $\mathrm{F}$ values of the proposed model are considered. In addition, representative leaf samples should be used to increase reliability of the model. Samples consisting of leaves of different sizes should be used to produce an accurate leaf area estimation equation. Otherwise, the equation will probably be unreliable. As measurement of the leaf area of plants such as grapevine is more complicated than for plants such as the peach tree, more samples are therefore required to produce an accurate model. Ackley et al. (1958) also noted calculations of the minimum number of leaves to provide a reliable linear measurement to area conversion modeling equation. So, any proposed model should be validated with independent data before being used for experiments. The use of a validated estimation model of leaf area is straightforward and saves time. However, developing a new leaf area model can be time-consuming, lasting for up to three months. For example, a large number of leaf samples of varying sizes can be collected, either from an orchard at different periods or, when leaves reach the desired size, from an orchard at one time.

\section{REGRESSION MODELS FOR SPECIFIC HORTICULTURAL CROPS}

\section{Fruit Crops}

Several leaf area prediction models for fruit species developed in previous studies are presented in table 1. Studies indicated that leaf area in the Stuart pecan can be estimated with reasonable accuracy and rapidity by employing the relationship of leaf area per terminal to terminal length (Sparks, 1966; Smith, 1992). A logarithmic model for nondestructive estimation of leaf area in cacao has also been developed by Reynolds (1971). A leaf area estimation model with high degree of correlation coefficient (0.961) has also been established by Kobayashi (1988) in guava. The length of the midrib, petiole and maximum width of the lamina in sour orange leaves were used to develop leaf area prediction models which exhibited a good predictive ability as indicated by $\mathrm{r}^{2}$ value of 0.93 (Ramkhelawan and Brathwaite, 1990). Using simple measure of leaf length and width, a nondestructive and cost effective measure for leaf area estimation of rabbit-eye blueberries was presented by NeSmith (1991). A strong correlation $\left(\mathrm{r}^{2}=\right.$ 0.96-0.98) between LA and various combinations of leaf length (L) and width (W) in certain cultivars of banana has been reported which can be exploited for prediction of leaf area in these fruits (Potdar and Pawar, 1991). Leaf area estimation model has also been offered for white mulberry (Satpathy, et al., 1992) with good correlation value $\left(r^{2}=0.960\right)$. Simple leaf area estimation equations have also been developed (Panta and NeSmith, 1995; Wu et al., 2010) for musk melon that offers reliable prediction of leaf area across several cultivars. By means of measuring leaf length (L) and width (W) Uzun and Celik 
(1999) achieved excellent equations for estimation of leaf area in avocado, grapes, kiwifruit, lotus plum, raspberry and red currant fruits. All models produced a coefficient of determination $\left(r^{2}\right)$ equal to or greater than 0.966. The length of midrib and the maximum width of lamina were used to develop nondestructive leaf area prediction models $\left(\mathrm{r}^{2}=0.997\right)$ in definite pistachio genotypes (Ranjbar an Damme, 1999). Models with high degree of correlation coefficients $\left(r^{2}=0.983,0.985\right)$ are also available for leaf area estimation in kiwifruits (Uzun and Celik, 1999; Williams and Martinson, 2003; Mendoza-de Gyves et al., 2007). Using the central vein length of papaya leaf Campostrini and Yamanishi (2001) were able to develop a logarithmic equation $\left(r^{2}=0.898\right)$ for assessment leaf area in papaya.

Studies on strawberry offered some reliable equations that predicts leaf area non-destructively by linear measurements of leaf geometry (Mandal et al., $2002-\mathrm{r}^{2}=0.993$; Demirsoy et al., $2005-\mathrm{r}^{2}=$ 0.991). Studies were also undertaken to generate suitable equations for nondestructive reliable estimation of leaf area in various cultivars of sweet cherry (Demirsoy and Demirsoy (2003a and 2003b; Cittadini and Peri, 2006; Demirsoy and Lang, 2010). In order to estimate the individual leaf area in custard apple Silva et al. (2004) were able to produce a plain equation with significant correlation value $\left(\mathrm{r}^{2}=0.770\right)$. A model for predicting the leaf area $\left(\mathrm{r}^{2}=0.998\right)$ was developed for peach by measuring lamina width, length and leaf area and the model was validated by measuring leaf samples of different peach trees (Demirsoy et al., 2004). An equation for estimating the leaf area in chestnut varieties was also derived $\left(\mathrm{r}^{2}=0.988\right)$ by measuring the lamina width, length and leaf area (Serdar and Demirsoy, 2006). Using linear measurements of leaf length (L), width $(\mathrm{W})$ and LA a simple equation was developed $\left(\mathrm{r}^{2}=0.982\right)$ for estimating leaf area in Hazelnut trees (Cristofori et al., 2007).

Fallovo et al. (2008) developed several models that could be used conveniently for estimating leaf area in small fruits (blackberry, gooseberry, blueberry, raspberry and redcurrent) with high $\mathrm{r}^{2}$ values (0.974 - 0.986). Cristofori et al. (2008) brought a simple equation $\left(\mathrm{r}^{2}=0.890\right)$ for analyzing the photosynthetic surface area accurately in persimmon. Odabas et al. (2009) developed a leaf area model for cherry laurel with significant $r^{2}$ value (0.95). Mazzini et al. (2010) derived an easy leaf area prediction model $\left(\mathrm{r}^{2}=0.997\right)$ for citrus trees. Rouphael et al. (2010a) suggested that length-width $(\mathrm{L} \times \mathrm{W})$ model can provide more accurate estimations of watermelon leaf area across cultivars than those based on single length (L) or width (W) measurement. Ghoreishi et al. (2012) provided a regression equation $\left(\mathrm{r}^{2}=0.865\right)$ for analyzing the leaf area in mango seedlings. Using a leaf area meter (Moghaddam, 2014) developed two linear models which were found as most accurate estimates for estimation of leaf area in $\operatorname{Red}\left(\mathrm{r}^{2}=\right.$ $0.94)$ and Golden $\left(r^{2}=0.98\right)$ delicious apples. Looking for an appropriate leaf area estimation equation in grapes various studies (Elsner and Jubb, 1988; Uzun and Celik, 1999; Montero et al., 2000; Williams and Martinson, 2003; Buttaro et al., 2015) customized a range of models with high degree of correlations $\left(\mathrm{r}^{2}=\right.$ 0.963 to 0.994 .) that can be used for nondestructive prediction of leaf area.

\section{Vegetable crops}

Leaf area prediction models for vegetables crops developed in previous studies are presented in table 2. Regression equations for inference of leaf area in summer squash (NeSmith, 1992), radish (Salerno, et al., 2005), faba bean (Peksen, 2007), green pepper (Ray and Singh 1989; De Swart, et al 2004; Cemek et al., 2011) and onion (Córcoles et al., 2015) are validated with strong correlation coefficient values. Kintomo and Ojo (2000) reported that a strong correlation existed between leaf area and various combinations of leaf length (L) and width (W) in grain amaranth (Amaranthus cruentus $\mathrm{L}$ ). Regression models are presented for LA prediction in each cultivar. Chien and Lin (2002) presented leaf area prediction models for edible amaranth ((A. mangostanus Linn.) and (A. inamoenus Willd), broccoli, cabbage and Chinese cabbage using elliptical hough transform. Various available models with regard to broccoli (Chien and Lin, 2002; Stoppani et al., 2003; Olfati et al., 2010) and cabbages (Chien and Lin, 2002; Olfati et al., 2010) with précised degree of correlation $\left(r^{2}=0.869-0.993\right.$ and $\left.r^{2}=0.985-0.953\right)$ presented striking opportunity of leaf area estimation in these crops.

Leaf area estimation through models as nondestructive means were attempted in cowpea, cucumber, okra as well as in tomato by previous workers (Blanco and Folegatti, 2003; Blanco and 
Folegatti, 2005: Carmassi et al., 2007: Tanko and Hassan, 2016) and predictive equations have been provided with good levels of significance $\left(\mathrm{r}^{2}=0.884-0.999\right)$. Rivera, et al., 2007 and Hinnah et al. (2014) suggested that for leaf area estimation in eggplant using the product between the linear measurements of length (L) and width (W) of the leaf blade allowed to obtain the satisfactory leaf area of plants nondestructively However, they suggested that quadratic equations with single dimension of length exhibited a high degree accuracy and precision in estimating individual LA of eggplant which also lowered the time of measurement. Regression analyses of LA versus FW, DW, L and W revealed several models for estimating the area of individual basil leaves (Bazaza et al., 2011) wherein the models, one based on the sum of dimension squares was found most accurate for Genovese $\left(r^{2}=0.895\right)$ while the product of dimension squares was the most suitable for Purple Ruffles $\left(r^{2}=0.817\right)$.

\section{Ornamental Crops}

The correlation equations between the actual and predicted leaf area as nondestructive mean of leaf area analysis have also been fashioned for certain vegetables crops (Table 3). Barbieri et al. (1994) suggested a non-destructive method of leaf area estímation from simple regression equation $\left(r^{2}=0.982\right)$. Leaf area can also be measured with the help of linear dimensions of leaf in sunflower; however, neither length nor breadth alone gave consistent LA estimation but both length and breadth measurements were needed for precise measurement of leaf area in sunflower (Bange, et al., 2000). Regression equations developed for Zennia elegans using leaf length and breadth revealed that leaf area prediction can be made accurately for different genotypes of Zennia using prediction models (Pintp et al., 2004). Chen and Lin (2004) suggested a nondestructive estimation of leaf area in Phalaenopsis using linear dimensions of leaf with high degree of coefficient correlation $\left(r^{2}=0.990\right)$. Similarly, Carmassi et al. (2007) advocated an empirical relationship between leaf area ans leaf dimensions in gerbera having $r^{2}$ and RMSE values of 0.910 and 14.71, respectively. Based on the simple L and W measurements, Fascella et al. (2009) presented a plain regression equation for leaf area estimation in Euphorbia with $\mathrm{r}^{2}$ value of 0.981. A linear model having $\mathrm{L} \times \mathrm{W}$ as the independent variable provided the most accurate estimate $\left(r^{2}=0.991\right.$; MSE $=0.726$ ) of LA in rose (Rouphael et al., 2010b). In order to estimate the leaf area in merremia, De Carvalho et al. (2011) described a clear relationship between the LA and dimensions principal, primary and secondary leaflets. Giuffrida et al. (2011) found that regression analysis of LA versus L and W or some combinations of these parameters resulted in several models that could be used for estimating the leaf area of individual bedding plants like pot marigold, dahlia, sweet William, geranium, petunia and pansy. They reported that a linear model having LW as the independent variable provided the most accurate estimate (highest $r^{2}$, smallest mean square error, and the smallest predicted residual error sum of squares) of LA in all bedding plants.

\section{Medicinal Crops}

Excellent relationships between the different dimensions and actual leaf area have also been reported by various workers in certain medicinal plants (Table 4). Working on nondestructive leaf estimation methods, Odabas et al. (2005) achieved some excellent models for estimation of leaf area in some medicinal plants wherein all $\mathrm{r}^{2}$ values and standard errors were found to be significant at the $\mathrm{P}<$ 0.001 level. To achieve a nondestructive leaf area estimation in summer snowflake Cirak et al. (2005b) develops a leaf area prediction model which was significantly correlated $\left(r^{2}=0.97\right)$ at 0.001 level. A highly significant $\left(r^{2}=0.99\right)$ leaf area prediction model was also produced for tea (Zenginbal et al. 2006). Leaf area prediction can be made in Stevia (sugar plant) either by using leaf area factor of 0.548 or the linear regression equation (Ramesh et al., 2007). Antunes et al. (2008) were able to establish an allometric model as single power for non-destructive leaf area estimation in coffee with excellent correlation coefficient $(\mathrm{r} 2=0.996)$ and standard error $(\mathrm{MSE}=0.0064)$ values. Odabas et al. (2009) accounted a non-destructive leaf area prediction model for "Kiraz" cherry laurel using leaf L, W and LA measurements with $\mathrm{r}^{2}$ value of 0.95 .

Several regression models were developed to predict the leaf area for saffron efficiently and nondestructively (Kumar, 2009). In order to develop a nondestructive technique of LA estimation in 
Bergenia purpurascens, Zhang and Liu (2010) obtained a regression equation with high degree of correlation coefficient $\left(r^{2}=0.950\right)$. Cirak et al. (2005a) found respectable relationships between leaf area and its different dimensions in selected medicinal plants. Studies revealed that irrespective of stages, the third leaf from the top has high correlation with total leaf area of the horse-eye bean plant. It was further observed that the area of the middle leaflet had significant relationship with total area of trifoliate leaf. The correction factors to find out the total leaf area of a plant from the leaflet area measurements were also worked out Dheebakaran G and Jagannathan R (2009). A linear model having L $\times$ W as the independent variables provided the most accurate estimate of leaf area for Picrorhiza kurroa, an endangered medicinal plant of Western Himalaya (Kumar and Sharma, 2013). Candido et al. (2013) describd a plain equation for estimation of leaf area in bush willows that was having high level of significance $\left(r^{2}=0.952\right)$. Accurate measure of the leaf area of Styrax pohlii and S. ferrugineus can be made by using the $\mathrm{LA}=0.582+0.683 \mathrm{WL}$ and $\mathrm{LA}=-0.666+0.704 \mathrm{WL}$ equations, respectively that exclude the necessity of leaf excisions and/ or expensive equipments (Souza and Habermann, 2014).

\section{ADVANTAGES AND DISADWANTAGES OF LEAF AREA ESTIMATION MODELS}

Models to predict leaf area non-destructively can provide researchers with many advantages in horticultural experiments. The most important advantages are as follows:

1. The models enable researchers to measure leaf area on the same plants during plant growth. The equations allow estimations of leaf growth from bud burst to leaf fall, and they reduce variability since the same leaf is used during the experiment. In addition, destructive leaf area measurements are not possible in many investigations. The use of equations eliminates the need for the detachment of leaves from plants.

2. Reliable models eliminate the need for expensive leaf area meters and labor.

3. Leaf area measurement is easy and quick if a reliable equation is obtained or chosen, thereby saving time.

4. In leaf measurements, consistent results are obtained by reliable equations, although non-consistent results may be obtained by a planimeter, depending upon hand manipulation.

5. Use of the modeling equations costs nothing.

In addition, Reynolds (1971) suggested that, in nutritional studies of young cacao cuttings, it became necessary to develop a rapid method for estimating leaf area. Ramkhelawan and Brathwaite (1990) stated that, in weed control investigations involving container-grown sour orange rootstocks, it became necessary to estimate leaf area by a non-destructive method. Kobayashi (1988) indicated that a rapid nondestructive method for estimating the leaf area of the guava in the field would be useful.

A considerable disadvantage of non-destructive methods is that, if the equation is unreliable, incorrect results may be obtained. To prevent this, leaf samples must be taken at different times and chosen at different sizes while an equation of the leaf area estimation is constructed. In addition, the equation should be tested or evaluated for each leaf at different sizes. Moreover, the obtained equation must be validated by other leaf samples before it is used in any experiment.

\section{CONCLUSION}

Nowadays, computer technology and mathematical modeling are progressing rapidly. These, and other developments, have advanced well. The developments have facilitated and accelerated our scientific studies. Therefore, benefiting from the opportunities is useful and necessary. This study is a mini-review that presents some leaf area estimation models with information regarding the advantages and disadvantage of their usage. Moreover, it gives suggestions about how an accurate mathematical model may be constructed. Most importantly, this mini-review shows that the models produced in previous studies for fruit species can be reliably used. 


\section{ACKNOWLEDGEMENT}

The authors are thankful to Dr. Y. Rouphael, Department of Crop Production, Faculty of Agricultural Engineering and Veterinary Medicine, Lebanese University, Dekwaneh-El Maten, Beirut, Lebanon for providing full length article published by them on this aspect which proved helpful in shaping of this article.

\section{REFERENCES}

1. Ackley, W.B., P.C. Crandall and T.S. Russell. 1958. The use of linear measurements in estimating leaf areas. Proc. Am. Soc. Hort. Sci., 72: 326-330.

2. Anderson, R.L., T. Robinson and G.A. Lang. 1999. Managing the Gisela cherry rootstocks. N.Y., Fruit Quart., 7: 19-22.

3. Antunes, W.C., M.F., Pompelli, D.M. Carretero and F.M. Da Matta. 2008. Allometric models for non-destructive leaf area estimation in coffee (Coffea arabica and Coffea canephora). Ann. Appl. Biol., 153: 33-40. (doi:10.1111/j.1744-7348.2008.00235.x)

4. Bange, M.P., G.L. Hammer, S.P. Milroy and K.G. Rickert. 2000. Improving estimates of individual leaf area of sunflower. Agron., 92:761-765 .

5. Barbieri, G., S. De Pascale, R. d'Andria and M. Mori. 1994. Estimating gladiolus leaf area by linear measurements. Adv. Hort. Sci., 8: 85-89

6. Bazaza, A.M., Z.K. Farimana, and M. Bannayan. 2011. Modeling individual leaf area of basil (Ocimum basilicum) using different methods. Intl. J. Plant Prod., 5 (4): 439-448.

7. Beerling, D.J. and J.C. Fry. 1990. A comparison of the accuracy, variability and speed of five different methods for estimating leaf area. Ann. Bot., 65: 483-488.

8. Beverly, R.B. and M.V. van Lersel. 1998. Calibration of a video image analysis system for measurement of stem length, leaf area, and percent ground coverage. Commun. Soil Sci. Plant Anal., 29: 1071-1081.

9. Blanco, F.F. and M.V. Folegatti. 2003. A new method for estimating the leaf area index of cucumber and tomato plants. Hortic. Bras., 21 (4): 666-669. http://dx. (doi.org/10.1590/S010205362003000400019)

10. Blanco, F.F. and M.V. Folegatti. 2005. Estimation of leaf area for greenhouse cucumber by linear measurement under salinity and grafting. Sci. Agric. (Piracicaba, Braz.), 62 (4): 305-309.

11. Blanke, M. 1995. Scanner for leaf area measurement - leaves keep their form, Garten. Mag., 3: 2728.

12. Buttaro, D., Y. Rouphael, C.M. Rivera, G. Colla and M. Gonnella. 2015. Simple and accurate allometric model for leaf area estimation in Vitis vinifera L. genotypes. Photosyn., 53 (3): $342-$ 348

13. Campostrini, E. and O.K. Yamanishi. 2001. Estimation of papaya leaf area using the central vein length. Sci. Agric. (Piracicaba, Braz.), 58 (1): 39-42.

14. Candido, W.S., M.F.B. Coelho, S.S.S. Maia, C.S.M. Cunhay and R.C.P. da Silva. 2013. Modelo para estimar a área foliar de Combretum leprosum Mart. Acta Agron., 2013, 62 (1): 37-41

15. Carmassi, G., L. Incrocci, G. Incrocci and A. Pardossi. 2007. Non-destructive estimation of leaf area in Solanum lycopersicum L. and gerbera (Gerbera jamesonii H. Bolus). Agr. Med., 137: 172-176.

16. Cemek, B., A. Unlukara and A. Kurunc. 2011. Nondestructive leaf area estimation and validation for green pepper (Capsicum annuum L.) grown under different stress conditions. Photosyn., 49 (1): 98 106 (doi: 10.1007/s11099-011-0010-6)

17. Chen, C. and R.S. Lin. 2004. Nondestructive estimation of dry weight and leaf area of Phalaenopsis leaves. Appl. Eng. Agric., 20 (4): 1-6

18. Chien, C.F. and T.T. Lin. 2002. Leaf area measurement of selected vegetable seedlings using elliptical Hough transform. Trans. ASAE, 45 (5): 1669-1677. 
19. Cirak, C., M.S. Odabas, B. Saglam and A.K. Ayan. 2005a. Relation between leaf area and dimensions of selected medicinal plants. Res. Agr. Eng., 51 (1): 13-19.

20. Cirak, C., M.S. Odabas and A.K. Ayan. 2005b. Leaf area prediction model for summer snowflake (Leucojum aestivumL.). Intl. J.Bot., 1: 12-14.

21. Cittadini, E.D. and L. Peri. 2006. Estimation of leaf area in sweet cherry using a non-destructive method. RIA (INTA), 35: 143-150.

22. Cittadini, E.D., M. Vallés, P. Peri, H. van Keulen, N. de Ridderand and M. Rodríguez. 2008. Effect of fruit-to-leaf area ratio on fruit quality and vegetative growth of 'Bing' sweet cherry trees at optimal leaf area index. Acta Hort. (ISHS), 795: 677-680.

23. Corcoles, J.I., A. Domínguez, M.A. Moreno, J.F. Ortega and J.A. de Juan. 2015. A non-destructive method for estimating onion leaf area. Irish J. Agric.Food Res., 54 (1): 17-30. (doi: 10.1515/ijafr2015-0002 IJAFR)

24. Cristofori, V., C. Fallovo, E. Mendoza-de Gyves, C.M. Rivera, C. Bignami and Y. Rouphael. 2008. Non-destructive analogue model for leaf area estimation in persimmon (Diospyros kaki L.) based on leaf length and width measurement. Europ. J. Horti. Sci., 73 (5): 216-221.

25. Cristofori, V., Y. Rouphael, E. Mendoza-de Gyves and C. Bignami. 2007. A simple model for estimating leaf area of hazelnut from linear measurements. Sci. Hort., 113 (2): 221-225.

26. Daughtry, C. 1990. Direct measurements of canopy structure. - Remore Sens., Rev., 5: 45-60.

27. De Carvalho, L.B., S. Bianco, V.C. Galati and A.R. Panosso. 2011. Determination of Merremia cissoides leaf area using the linear measures of the leaflets. Acta Sci. Agron., 33 (3): 473-476.

28. De Swart, E.A.M., R. Groenwold, H.J. Kanne, P. Stam, L.F.M. Marcelis and R.E. Voorrips. 2004. Non-destructive estimation of leaf area for different plant ages and accessions of Capsicum annиum L. J. Hort. Sci. \& Biotech., 79 (5): 764-770.

29. Demirsoy, H. 2009. Leaf area estimation in some species of fruit tree by using models as a nondestructive method. Fruits, 64: 45-51. (doi: 10.1051/fruits/2008049)

30. Demirsoy, H. and G.A. Lang. 2010. Validation of a leaf area estimation model for sweet cherry. Span. J. Agric. Res., 8 (3): 830-832.

31. Demirsoy, H. and L. A. Demirsoy. 2003a. Validated leaf area prediction model for some cherry cultivars in Turkey. Pak. J. Bot., 35: 361-367.

32. Demirsoy, H., L. Demirsoy, and A. 2005. Ozturk, Improved model for the non-destructive estimation of strawberry leaf area. Fruits, 60(1): 69-73. (doi: 10.1051/fruits:2005014)

33. Demirsoy, H., L. Demirsoy, S. Uzun and B. Ersoy. 2004. Nondetructive leaf area estimation in peach. Europ J. Hort. Sci., 69 (4) S: 144-46.

34. Demirsoy, L. and H. Demirsoy. 2003b. Leaf area estimation model for some local cherry genotypes in Turkey. Pak. J. Biol. Sci., 6: 153-156.

35. Dheebakaran, G. and R. Jagannathan. 2009. Estimation of total leaf area by non-destructive methods in horse-eye bean (Mucuna pruriens). Madras Agric. J., 96 (1-6): 113-115.

36. Ebert, G. 1995. Leaf area measurement with laser optics. Erwerbs Obstbau, 37: 87-188.

37. El-Boray, M.S., A.M. Shalam and Z.M. Khouri. 2013. Effect of different thinning techniques on fruit set, leaf area, yield and fruit quality parameters of Prunus persica L. Batsch cv. Floridaprince. Tren. Hort. Res., 3: 1-13.

38. Elsner, E.A. and G.L. Jubb. 1988. Leaf area estimation of concord grape leaves from simple linear measurements. Am. J. Enol. Vitic., 39: 95-97.

39. Fallovo, C., V. Cristofori, E. Mendoza-de Gyves, C.M. Rivera, R. Rea and S. Fanasca. 2008. Leaf area estimation model for small fruits from linear measurements. HortSci., 43(7): 2263-2267.

40. Fascella, G., S. Darwich and Y. Rouphael. 2013. Validation of a leaf area prediction model proposed for rose. Chil. J. Agric. Res., 73(1): 73-76. (http://dx.doi.org/10.4067/S0718-58392013000100011)

41. Fascella, G., P. Maggiore, G. Zizzo, G. Colla and Y. Rouphael. 2009. A simple and low-cost method for leaf area measurement in Euphorbia $\times$ lomi Thai hybrids. Adv. Hort. Sci., 23: 57-60. 
42. Fladung, M. and E. Ritter. 1991. Plant leaf area measurements by personal computers, J. Agron. Crop Sci., 166: 69-70.

43. Gamiely, S., W.M. Randle, H.A. Mills, and D.A. Smittle. 1991. A rapid and non-destructive method for estimating leaf area of onions. HortSci., 26: 206.

44. Ghoreishi, M., Y. Hossini, and M. Maftoon. 2012. Simple models for predicting leaf area of mango (Mangifera indica L.). J. Biol Earth Sci., 2 (2): B45-B53.

45. Giuffrida, F., Y. Rouphael, S. Toscano, D. Scuderi, D. Romano, C.M. Rivera, G. Colla and C. Leonardi. 2011. A simple model for nondestructive leaf area estimation in bedding plants. Photosyn., 49 (3): 380-388.

46. Hinnah, F.D., A.B. Heldwein, I.C. Maldaner, L.H. Loose, D.D.P. Lucas and M.P. Bortoluzzi. 2014. Estimation of eggplant leaf area from leaf dimensions. Bragantia, 73 (3): 213-218.

47. Igathinathane, C., V.S.S. Prakash, U. Padma, G.R. Babu, and A.R. Womac. 2006. Interactive computer software development for leaf area measurement, Comput. Electron. Agric., 51: 1-16.

48. Jorquera-Fontena, E., M. Alberdi, and N. Franck. 2014. Pruning severity affects yield, fruit load and fruit and leaf traits of 'Brigitta' blueberry. J. Soil Sci. Plant Nutr., 14 (4): 855-868.

49. Kintomo, A.A. and O.D. Ojo. 2000. Non-destructive leaf area estimation in grain amaranth (Amaranthus cruentus L.). Res. Crops, 1 (3): 267-270.

50. Kobayashi, K.D. 1988. Estimating leaf area of 'Beaumont' guava, Trop. Agric., 65: 173-175.

51. Kumar, R. 2009. Calibration and validation of regression model for non-destructive leaf area estimation of saffron (Crocus sativus L.). Sci. Hort., 122 (1): 142-145

52. Kumar, R. and S. Sharma. 2013. Simulation and validation of leaf area prediction model for Picrorhiza kurroa - An endangered medicinal plant of Western Himalaya. J. Med. Plants Res., 7(20): 1467-1474. (doi: 10.5897/JMPR12.967)

53. Lang, G.A. 2000. Precocious, dwarfing and productive - How will new cherry rootstocks impact the sweet cherry industry? HortTechnol., 10: 719-725.

54. Lang, G.A. 2005. Underlying principles of high density sweet cherry production. Acta Hort., 667: $325-335$.

55. Lu, H.Y., C.T., Lu, M.L. Wei and F.L. Chan. 2004. Comparison of different models for nondestructive leaf area estimation in Taro. Agron. J., 96: 448-453.

56. Mandal, K.K., S.K. Ghosh, and P. Gayen. 2002. A nondestructive way of leaf area estimation in the strawberry. Ann. Biol., 18: 19-24.

57. Manivel, L. and R.J. Weaver. 1974. Biometric correlations between leaf area and length measurements of 'Grenache' grape leaves. HortSci., 9: 27-28.

58. Mazzini, R.B., R.V. Ribeiro and R.M. Pio. 2010. A simple and non-destructive model for individual leaf area estimation in citrus. Fruit, 55 (5): 269-275. www.fruits-journal.org (doi: 10.1051/fruits/2010022)

59. Mendoza-de Gyves, E., Y. Rouphael, V. Cristofori, and F.R. Mira. 2007. A non-destructive, simple and accurate model for estimating the individual leaf area of kiwi (Actinidia deliciosa). Fruits, 62: 171-176.

60. Moghaddam, P.A. 2014. Quick estimation of apple (Red Delicious and Golden Delicious) leaf area and chlorophyll content. Iran Agric. Res., 33 (1): 53-62.

61. Montero, F.J., J.A. de Juan, A. Cuesta and A. Brasa. 2000. Nondestructive methods to estimate leaf area in Vitis vinifera L. HortSci., 35 (4): 696-698.

62. Mori, S., T. Kawasaki, and L. Takeuchi. 1991. Nondestructive measurement of the growth of leaf area by means of a portable copying machine. J. Jpn. For. Soc., 73: 298-300.

63. NeSmith, D.S. 1992. Estimating summer squash leaf area non-destructively. HortSci., 27 (1): 77.

64. NeSmith, D.S. 1991. Non-destructive leaf area estimation of rabbit-eye blueberries. HortSci., 26: 132. 
65. Odabas, M.S., H. Celik, and A. Islam. 2009. Non-destructive leaf area prediction model for "Kiraz" cherry laurel (Laurocerasus officinalis Roem.). Europ. J. Plant Sci. Biotech., 3(special issue 1): 9799.

66. Odabas, M.S., K.. Kevserogiu, C. Cirak, and B. Saglam. 2005. Non-destructive estimation of leaf area in some medicinal plants. Turk J. Field Crops, 10: 29-36.

67. Olfati, J.A., G. Peyvast, H. Shabani, and Z. Nosratie-Rad. 2010. An estimation of individual leaf area in cabbage and broccoli using non-destructive methods. J. Agr. Sci. Tech., 12: 627-632.

68. Pandey, S.K. and H. Singh. 2011. A simple, cost-effective method for leaf area estimation. J. Bot. vol. 2011, Article ID 658240, 6 pages, 2011. doi:10.1155/2011/658240

69. Panta, G.R. and D.S. NeSmith. 1995. A model for estimating area of muskmelon leaves, HortSci., 30.(3):624-625.

70. Peksen, E. 2007. Non-destructive leaf area estimation model for faba bean (Vicia faba L.). Sci. Hortic., 113: 322-328.

71. Pinto, A.C.R., T.J.D. Rodrigues, J.C. Barbosa and I.C. Leite. 2004. Leaf area prediction models for Zinnia elegans JACQ, Zinnia haageana REGEL and Profusion Cherry. Sci. Agric. (Piracicaba, Braz.), 61 (1): 47-52.

72. Potdar, M.V. and K.R. Pawar. 1991. Non-destructive leaf area estimation in banana. Sci. Hortic., 45 : 251-254.

73. Prasada Rao, G.S., B.H. Khan, and K.L. Chadha. 1978. Comparison of methods of estimating leaf surface area through leaf characteristics in some cultivars of Mangifera indica. Sci. Hortic, 8: 341348.

74. Ramesh, K., N. Ramawat, and V. Singh. 2007. Leaf area distribution pattern and non-destructive estimation methods of leaf area for Stevia rebaudiana (Bert.) Bertoni. Asian J. Plant Sci., 6 (7): 103743.

75. Ramkhelawan E. and R.A.I. Brathwaite. 1990. Leaf area estimation by non destructive methods in sour orange (Citrus aurantium L.). Trop. Agric., 67: 203-206.

76. Ranjbar, A. and P. Damme. 1999. Estimation of leaf area by non-destructive methods in three Iranian pistachio species (Pistacia mutica subsp. cabulica, Pistacia khinjuk subsp. oblonda and Pistacia khinjuk subsp. populifolia). Mededelingen - Fac. Landbouwkd. Toegep. Biol. Wet. Univ. Gent, 64 (2) 49-56.

77. Ray, J.C. and R.P. Singh. 1989. Leaf area estimation in capsicum (Capsicum annuum L.). Sci. Hort., 39: $181-188$.

78. Reynolds, S.G.A. 1971. A note on estimation of leaf areas of Cacao (Theobroma cacao L.) from three leaf parameters. Trop. Agric., 48: 177-179.

79. Rivera, C.M., Y. Rouphael, M. Cardarelli, and G. Colla. 2007. A simple and accurate equation for estimating individual leaf area of eggplant from ILinear measurements. Europ. J. Hort. Sci., 70: 228230.

80. Robbins, N.S. and D.M. Pharr. 1987. Leaf area prediction models for cucumber from linear measurements. HortSci., 22: 1264-1266.

81. Rouphael, Y., M. Cardarelli, A. Marucci, and G. Colla. 2010a. Allometric models for non-destructive leaf area estimation in grafted and ungrafted watermelon (Citrullus lanatus Thunb.). J. Food Agric. Environ., 8(1): 161-165.

82. Rouphael, Y., A.H. Mouneimne, A. Ismail, E. Mendoza-de Gyves, C.M. Rivera and G. Colla. 2010 b. Modeling individual leaf area of rose (Rosa hybrida L.) based on leaf length and width measurement. Photosyn., 48: 9-15.

83. Salerno Rivera, A.C.M., Y. Rouphael, G. Colla, M. Cardarelli, F. Pierandrei, E. Rea and F. Saccardo 2005. Leaf area estimation of radish from simple linear measurements. Adv. Hortic. Sci., 19 (4): 213215. 
84. Satpathy, B., A. Shivnath, K.M. Rao, P.L. Ghosh, and B.P. Nair. 1992. An easy and rapid method of leaf area estimation in white mulberry (Morus alba). Indian J. Agric. Sci., 62: 489-491.

85. Sepulveda, G.R. and W.M. Kliewer. 1983. Estimation of leaf area of two grapevine cultivars (Vitis vinifera L.) using laminae linear measurements and fresh weight. Am. J. Enol. Vitic., 34: 221-226.

86. Serdar, U. and H. Demirsoy. 2006. Non-destructive leaf area estimation in chestnut. Sci. Hortic., 108 (2): 227-30.

87. Silva, P.S.L.E., D. Barbin, R.J. De Sousa Goncalves, J.D. Da Cruz Firmino, and I.C. Fonseca. 2004. Leaf area estimates of custard apple tree progenies. Rev. Bras. Frutic. (Jaboticabal - SP), 26 (3): 558560.

88. Smith, M.W. 1992. A nondestructive method for estimation of leaf area in pecan. HortSci., 27(7):851.

89. Smith, W.K., A.W. Schoettle, and M. Cui. 1991. Importance of the method of leaf area measurement to the interpretation of gas exchange of complex shoots. Tree Physiol., 8: 121-127.

90. Souza, M.C. and G. Habermann. 2014. Non-destructive equations to estimate the leaf area of Styrax pohlii and Styrax ferrugineus. Braz. J. Biol., 74 (1): 222-25. http://dx.doi.org/10.1590/15196984.17012.

91. Sparks, D. 1966. A rapid method for estimating the leaf area of the Stuart pecan, Carya illinoensis Koch. HortSci., 1: 93-94.

92. Stoppani, M.I., R. Wolf, N. Francescangeli, and H.R. Marti. 2003. A non-destructive and rapid method for estimating leaf area of broccoli. Adv. Hort., Sci., 17 (3): 173-75.

93. Tanko, M.U. and U.T. Hassan. 2016. Leaf area determination for maize (Zea mays L), Okra (Abelmoschus esculentus L) and cowpea (Vigna unguiculata L) crops using linear measurements. $J$. Biol. Agric. Healthcare, 6 (4): 103-111.

94. Uzun, S. and H. Celik. 1999. Leaf area prediction models (Uzçelik-I) for different horticultural plants. Tr. J. of Agric. Forest., 23: 645-650.

95. Williams, L. and T.E. Martinson. 2003. Non-destructive leaf area estimation of 'Niagara' and 'De Chaunac' grapevines. Sci. Hortic., 98: 493-498.

96. Wu, H., L. Chan, M. Wei, and H. Lu. 2006. A simple and inexpensive technique for estimating leaf surface area of muskmelon (Cucumis melo L.). J. Taiwan Agric. Res., 2010, 59 (2): 71-77.

97. Zenginbal, H., M. Ozcan, S. Uzum. and C. Cirak. 2006. Non-destructive estimation of leaf area in tea (Camelia sinensis). Res. J. Bat., 1 (1): 46-51.

98. Zhang, L. and X. Liu. 2010. Nondestructive leaf area estimation of Bergenia purpurascens across timberline ecotone, South-east Tibet. Ann. Bot. Fennici., 47: 346-52. 


\section{(Tables \& Figures)}

Table 1. Useful leaf area estimation models developed through various studies for fruit crops

\begin{tabular}{|c|c|c|c|c|}
\hline Common/ scientific name & Variety & Model & $\mathbf{R}^{2}$ & Reference \\
\hline Apple (Malus domestica) & Red Delicious & $\mathrm{LA}=1.01+0.82 \times \mathrm{L} \times \mathrm{W}$ & 0.940 & $(60)$ \\
\hline Apple (Malus domestica) & Golden Delicious & $\mathrm{LA}=1.23+0.87 \times \mathrm{L} \times \mathrm{W}$ & 0.940 & $(60)$ \\
\hline Avocado (Persea Americana L.) & General & $\mathrm{LA}=-50.63-1.353 \mathrm{~L} / \mathrm{W}+5.347 \times \mathrm{W}+0.6 \times \mathrm{W}^{2}+5.489 \times \mathrm{L}$ & 0.983 & $(94)$ \\
\hline Banana (Musa $\times$ paradisiacal) & Ardhapuri & $\mathrm{LA}=-0.0334+0.8402 \times \mathrm{L} \times \mathrm{W}$ & 0.960 & $(72)$ \\
\hline Banana (Musa $\times$ paradisiacal) & Basrai & $\mathrm{LA}=0.0266+0.7629 \times \mathrm{L} \times \mathrm{W}$ & 0.980 & $(72)$ \\
\hline Blackberry (Rubus fruticosus L.) & General & $\mathrm{LA}=0.90+0.70 \times \mathrm{L} \times \mathrm{W}$ & 0.975 & (39) \\
\hline Cacao (Theobroma cacao) & General & $\log \mathrm{LA}=-0.632+1.987 \log \mathrm{L}$ & 0.998 & $(78)$ \\
\hline $\begin{array}{l}\text { Cherry Laurel (Laurocerasus officinalis } \\
\text { Roem.) }\end{array}$ & Kiraz & $\begin{array}{l}\mathrm{LA}=(-55.5877)+(19.98318 \times \mathrm{W})+\left(-0.83723 \times \mathrm{W}^{2}\right)+(0.143132 \times \\
\left.\mathrm{L}^{2}\right)\end{array}$ & 0.950 & (65) \\
\hline Chestnut (Fagus castanea) & General & $\mathrm{LA}=3.36+0.11 \mathrm{~L} 2-0.26\left(\mathrm{~L}^{2} / \mathrm{W}^{2}\right)+1.1 \times \mathrm{W}^{2}$ & 0.988 & $(86)$ \\
\hline Citrus (Citrus species) & General & $\mathrm{LA}=0.680(\mathrm{~L} \times \mathrm{W})-0.103$ & 9.997 & $(58)$ \\
\hline Custard Apple (Annona squamosa L.) & General & $\mathrm{LA}=0.72 \times \mathrm{L} \times \mathrm{W}$ & 0.770 & (87) \\
\hline Gooseberry (Ribes grossularia L.) & General & $\mathrm{LA}=0.58+0.72 \times \mathrm{L} \times \mathrm{W}$ & 0.974 & (39) \\
\hline Grape (Vitis vinifera L.) & General & $\mathrm{LA}=0.465+0.914 \times \mathrm{L} \times \mathrm{W}$ & 0.981 & $(12)$ \\
\hline Grape (Vitis vinifera L.) & Niagara & $\mathrm{LA}=0.637 \times \mathrm{W}^{1.995}$ & 0.982 & (95) \\
\hline Grape (Vitis vinifera L.) & DeChaunac & $\mathrm{LA}=0.672 \times \mathrm{W}^{1.963}$ & 0.963 & $(95$ \\
\hline Grape (Vitis vinifera L.) & Concord & $\mathrm{LA}=-3.01+0.85 \times \mathrm{W} \times \mathrm{L}$ & 0.984 & $(38)$ \\
\hline Grape (Vitis vinifera L.) & Isabella & $\mathrm{LA}=-114.43-58.48 \mathrm{~L} / \mathrm{W}+0.651 \mathrm{~W}^{2}+210.86(\mathrm{~L} / \mathrm{W})$ & 0.986 & (94) \\
\hline Grape (Vitis vinifera L.) & Narince & $\mathrm{LA}=-114.43-65.79 \mathrm{~L} / \mathrm{W}+0.651 \mathrm{~W}^{2}+210.86(\mathrm{~L} / \mathrm{W})$ & 0.986 & (94) \\
\hline Grape (Vitis vinifera L.) & Cencibel & $\mathrm{LA}=0.587 \times \mathrm{L} \times \mathrm{W}$ & 0.994 & (61) \\
\hline Guava (Psidium guajava) & General & $\mathrm{LA}=16.44-3.11 \times \mathrm{L}+0.58 \mathrm{~L} 2$ & 0.961 & $(50)$ \\
\hline Hazelnut (Corylus avellana) & General & $\mathrm{LA}=2.59+0.74 \times \mathrm{L} \times \mathrm{W}$ & 0.982 & $(25)$ \\
\hline
\end{tabular}


IRA-International Journal of Applied Sciences

\begin{tabular}{|c|c|c|c|c|}
\hline $\begin{array}{l}\text { Highbush blueberry } \quad \text { (Vaccinium } \\
\text { corymbosum L.) }\end{array}$ & General & $\mathrm{LA}=0.54+0.68 \times \mathrm{L} \times \mathrm{W}$ & 0.986 & $(39)$ \\
\hline Kiwifruit (Actinidia deliciosa A. Chev.) & General & $\mathrm{LA}=-50.63-5.412(\mathrm{~L} / \mathrm{W})+5.347 \times \mathrm{W}+0.24 \times \mathrm{W}^{2}+5.489 \times \mathrm{L}$ & 0.983 & $(94,95)$ \\
\hline Kiwifruit (Actinidia deliciosa A. Chev.) & Hayward & $\mathrm{LA}=0.82(\mathrm{~L} \times \mathrm{W})-0.28$ & 0.985 & (59) \\
\hline Lotus plum (Prunus domestica) & General & $\mathrm{LA}=-50.63-2.706(\mathrm{~L} / \mathrm{W})+5.347 \times \mathrm{W}+0.12 \times \mathrm{W}^{2}+5.489 \times \mathrm{L}$ & 0.983 & (94) \\
\hline Mango (Mangifera indica L) Seedling & Seedling & $\mathrm{LA}=0.2452(\mathrm{~L} \times \mathrm{W}) \times \mathrm{N}$ & 0.865 & (44) \\
\hline Muskmelon (Cucumis melo) & General & $\mathrm{LA}=-2.47+0.86(\mathrm{~L} \times \mathrm{W})$ & 0.98 & $(69)$ \\
\hline Muskmelon (Cucumis melo) & Tianhun & $\mathrm{LA}=0.67 \times \mathrm{L} \times \mathrm{W}$ & 0.988 & (96) \\
\hline Muskmelon (Cucumis melo) & Chioumih & $\mathrm{LA}=0.73 \times \mathrm{L} \times \mathrm{W}$ & 0.989 & $(96)$ \\
\hline Muskmelon (Cucumis melo) & Zhufen & $\mathrm{LA}=0.65 \times \mathrm{L} \times \mathrm{W}$ & 0.994 & $(96)$ \\
\hline Papaya (Carica papaya) & General & $\log \mathrm{LA}=0.315+1.85 \log \mathrm{LLCV}$ & 0.898 & (13) \\
\hline Persimon (Diospyros kaki L.) & General & $\mathrm{LA}=3.83+0.69 \times \mathrm{L} \times \mathrm{W}$ & 0.98 & $(24)$ \\
\hline Peach (Prunus persica) & General & $\mathrm{LA}=-0.5+0.23 \times \mathrm{L} / \mathrm{W}+0.67 \times \mathrm{L} \times \mathrm{W}$ & 0.998 & (33) \\
\hline Pistachio (Pistacia khinjuk subsp. oblonga) & General & $\mathrm{LA}=(\mathrm{L} 1 \times \mathrm{W} 1)+(\mathrm{L} 2 \times \mathrm{W} 2)+(\mathrm{L} 3 \times \mathrm{W} 3)$ & 0.960 & (76) \\
\hline Pistachio (Pistacia mutica subsp. capulica) & General & $\mathrm{LA}=(\mathrm{W} 1+\mathrm{W} 2+\mathrm{W} 3)$ & 0.980 & (76) \\
\hline Blueberry (Vaccinium virgatum) & Rabbiteye & $\mathrm{LA}=0.31+0.62 \times \mathrm{L} \times \mathrm{W}$ & 0.950 & (64) \\
\hline Raspberry (Rubus idaeus L.) & General & $\mathrm{LA}=0.03+0.71 \times \mathrm{L} \times \mathrm{W}$ & 0.982 & $(39)$ \\
\hline Raspberry - Red (Rubus idaeus $\times$ strigosus & Rubin & $\mathrm{LA}=-148.65-33.46 \mathrm{LLL}+29.764 \mathrm{ULL}+29.72 \mathrm{LLL}$ & 0.988 & $(94)$ \\
\hline Redcurrant (Rubes rubrum L.) & General & $\mathrm{LA}=1.72+0.69 \times \mathrm{L} \times \mathrm{W}$ & 0.980 & $(39)$ \\
\hline Red currant (Rubes rubrum L.) & General & $\mathrm{LA}=-114.43-73.1(\mathrm{~L} / \mathrm{W})+0.651 \mathrm{~W} 2+210.86(\mathrm{~L} / \mathrm{W})$ & 0.966 & $(94)$ \\
\hline Sour orange (Citrus aurantium $\mathrm{L}$ ) & General & $\mathrm{LA}=0.79+1.45 \times \mathrm{W}$ & 0.930 & (75) \\
\hline Strawberry (Fragaria $\times$ ananassa $)$ & General & LA $=1.89+2.145 \times$ upper lobe length $\times$ left lobe width & 0.993 & $(32)$ \\
\hline Strawberry (Fragaria $\times$ ananassa $)$ & General & LA $=1.89+2.145 \times($ upper lobe length $) \times($ left lobe width $)$ & 0.993 & $(32)$ \\
\hline Strawberry $($ Fragaria $\times$ ananassa $)$ & General & $\mathrm{LA}=165.91(\mathrm{X})-2716.35$ or $\mathrm{LA}=161.03(\mathrm{X} 1)-2121.8$ & 0.951 & $(56)$ \\
\hline Stuart pecan (Carya illinoensis) & General & $\begin{array}{l}\text { Log LA (for leaflet })=-0.3088+1.6990 \log (\text { midrib length }) \\
\text { LA per terminal }=192.0+89.8 \text { terminal length. }\end{array}$ & 0.993 & $(91,88)$ \\
\hline
\end{tabular}


IRA-International Journal of Applied Sciences

\begin{tabular}{|c|c|c|c|c|}
\hline Sweet cherry (Prunus avium L.), & General & $\mathrm{LA}=6.84-2.36 \times \mathrm{L}+0.14 \times \mathrm{L}^{2}-0.016 \times \mathrm{W} \times \mathrm{L}^{2}+0.84 \times \mathrm{W} \times \mathrm{L}$ & 0.981 & $(30,31)$ \\
\hline $\begin{array}{l}\text { Sweet Cherry (Prunus avium L.) Tatura - } \\
\text { TS) }\end{array}$ & Van & $\mathrm{LA}=0.678 \times \mathrm{L} \times \mathrm{W}$ & 0.994 & $(21)$ \\
\hline $\begin{array}{l}\text { Sweet Cherry (Prunus avium L.), Tatura - } \\
\text { TS) }\end{array}$ & Lapins & $\mathrm{LA}=0.662 \times \mathrm{L} \times \mathrm{W}$ & 0.994 & $(21)$ \\
\hline $\begin{array}{l}\text { Sweet Cherry (Prunus avium L.), Tatura - } \\
\text { TS) }\end{array}$ & Bing & $\mathrm{LA}=0.656 \times \mathrm{L} \times \mathrm{W}$ & 0.994 & $(21)$ \\
\hline Sweet Cherry (Prunus avium L.) Vase - TS & Van & $\mathrm{LA}=0.670 \times \mathrm{L} \times \mathrm{W}$ & 0.994 & $(21)$ \\
\hline Sweet Cherry (Prunus avium L.) Vase - TS & Lapins & $\mathrm{LA}=0.654 \times \mathrm{L} \times \mathrm{W}$ & 0.994 & (21) \\
\hline Sweet Cherry (Prunus avium L.) Vase - TS & Bing & $\mathrm{LA}=0.644 \times \mathrm{L} \times \mathrm{W}$ & 0.994 & $(21)$ \\
\hline Sweet cherry (Prunus avium L.) & General & $\mathrm{LA}=6.84-2.36 \mathrm{~L}+0.14 \mathrm{~L} 2-0.016 \times \mathrm{W} \times \mathrm{L}^{2}+0.84 \times \mathrm{W} \times \mathrm{L}$ & 0.981 & $(34)$ \\
\hline Sweet cherry (Prunus avium L.) & General & $\mathrm{LA}=0.6612 \times \mathrm{L} \times \mathrm{W}$ & 0.993 & $(21)$ \\
\hline Sweet cherry (Prunus avium L.) & Lambert & $\begin{array}{l}\mathrm{LA}=-21.73+2.59 \times \mathrm{W}+4.76 \times \mathrm{L}-0.23 \times \mathrm{L}^{2}+0.034 \times \mathrm{WL}^{2}-0.004 \\
\times \mathrm{L}^{2}\end{array}$ & 0.996 & $(31)$ \\
\hline Sweet cherry (Prunus avium L.) & 0900 Ziraat & $\begin{array}{l}\mathrm{LA}=-21.37+2.59 \times \mathrm{W}+4.76 \times \mathrm{L}-0.23 \times \mathrm{L}^{2}+0.034 \times \mathrm{W} \times \mathrm{L}^{2}- \\
0.006 \times \mathrm{L}^{2}\end{array}$ & 0.996 & $(31)$ \\
\hline Sweet cherry (Prunus avium L.) & Van & $\begin{array}{l}\mathrm{LA}=-21.01+2.59 \times \mathrm{W}+4.76 \times \mathrm{L}-0.23 \times \mathrm{L}^{2}+0.034 \times \mathrm{W} \times \mathrm{L}^{2}- \\
0.008 \times \mathrm{L}^{2}\end{array}$ & 0.996 & $(31)$ \\
\hline Sweet cherry (Prunus avium L.) & Bing & $\begin{array}{l}\mathrm{LA}=-20.65+2.59 \times \mathrm{W}+4.76 \times \mathrm{L}-0.23 \times \mathrm{L}^{2}+0.034 \times \mathrm{W} \times \mathrm{L}^{2}- \\
0.001 \times \mathrm{L}\end{array}$ & 0.996 & $(31)$ \\
\hline Sweet cherry (Prunus avium L.) & Stella & $\begin{array}{l}\mathrm{LA}=-19.93+2.59 \times \mathrm{W}+4.76 \times \mathrm{L}-0.23 \times \mathrm{L}^{2}+0.034 \times \mathrm{W} \times \mathrm{L}^{2}- \\
0.014 \times \mathrm{L}^{2}\end{array}$ & 0.996 & $(31)$ \\
\hline Watermelon (Citrullus lanatus (Thunb) & General & $\mathrm{LA}=2.99+0.50 \times \mathrm{L} \times \mathrm{W}$ & 0.961 & $(81)$ \\
\hline White mulberry (Morus alba) & General & $\mathrm{LA}=-2.12+0.68 \times(\mathrm{L} \times \mathrm{W})$ & 0.960 & $(84)$ \\
\hline
\end{tabular}

LA - leaf area; L - leaf length; $\mathrm{W}$ - leaf breadth; $\mathrm{N}$ - no. of leaves per seedling; L1, L2, L3 are the length of the apical leafs midrib, the length of the first leaflet nearest to the apical leaf on the left and the length of the first leaflet nearest to the apical leaf on the right, respectively; and W1, W2, W3 are the maximum width of lamina for L1, L2 and L3 respectively; LLCV - length of the leaf central vein; LLL - lower leaflet length; $\mathrm{ULL}$ - upper leaf lobe length; X - width of the top of the leaflet; X1 - the width of the side of the leaflet; TS - training system. 
IRA-International Journal of Applied Sciences

Table 2. Useful leaf area estimation models developed through various studies for vegetable crops

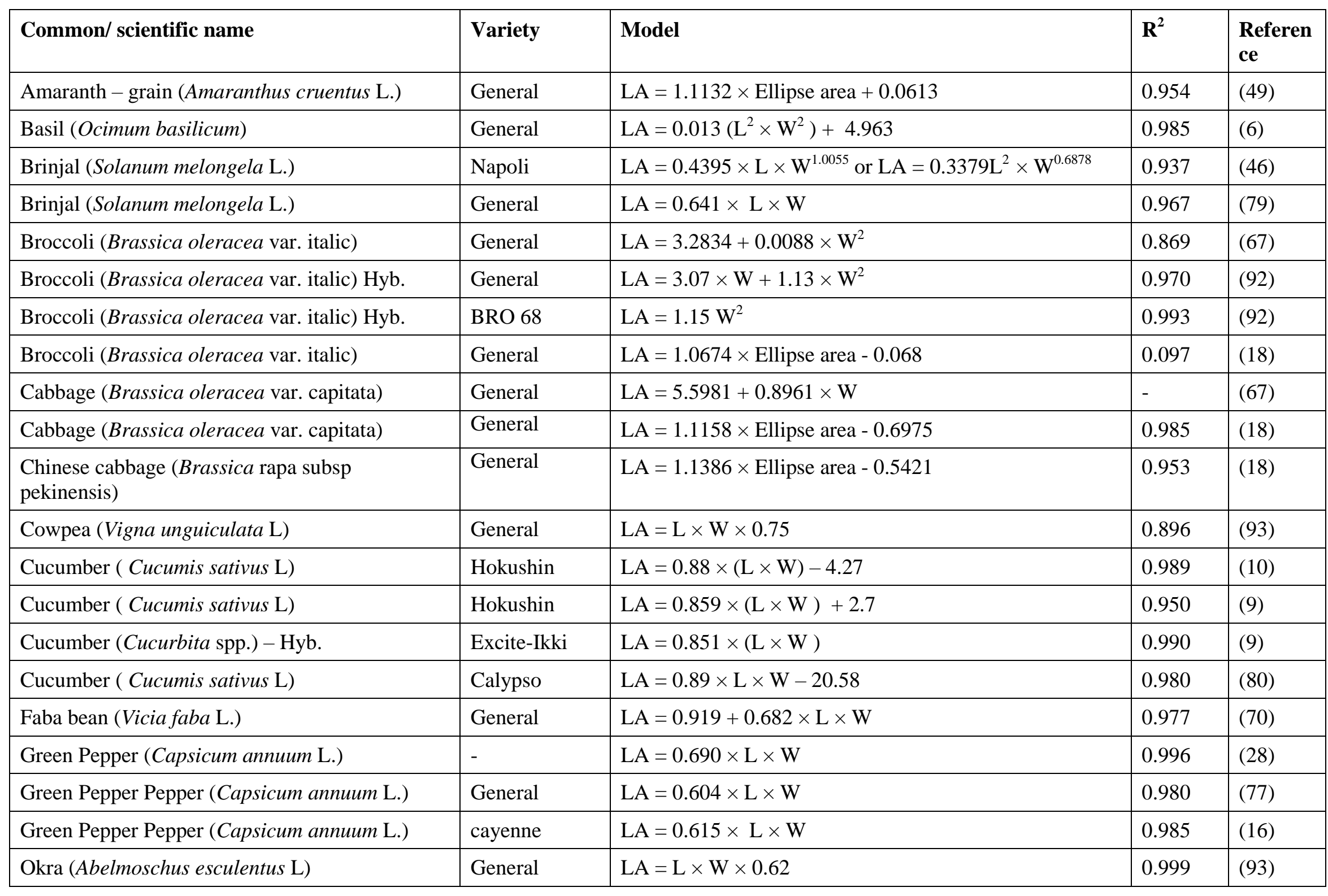


IRA-International Journal of Applied Sciences

\begin{tabular}{|c|c|c|c|c|}
\hline Onion (Allium cepa) & Pandero & $\mathrm{LA}=0.000199+1.277 \times \mathrm{L} \times \mathrm{A} 25$ & 0.925 & (23) \\
\hline Radish (Raphanus sativus) & - & $\mathrm{LA}=1.636+0.193(\mathrm{~L} \times \mathrm{W})+0.74\left(\mathrm{~W}^{2}\right)+0.975 \times \mathrm{L}$ & 0.97 & $(83)$ \\
\hline $\begin{array}{l}\text { Red cabbage (Brassica oleracea var. capitata f. } \\
\text { rubra) }\end{array}$ & General & $\mathrm{LA}=-338.88+3.2859 \times \mathrm{W}$ & 0.915 & $(67)$ \\
\hline Summer Squash (Cucurbita pepo) & General & $\mathrm{LA}=-8.4+0.97(\mathrm{~L} \times \mathrm{W})$ & 0.983 & (63) \\
\hline Tomato (Solanum lycopersicum L) Hybrid & Facundo & $\mathrm{LA}=0.347(\mathrm{~L} \times \mathrm{W})-10.7$ & 0.980 & (9) \\
\hline
\end{tabular}

LA - leaf area; A25 - Leaf diameter at a distance of $25 \%$ of the total leaf length

Table 3. Useful leaf area estimation models developed through various studies for ornamental crops

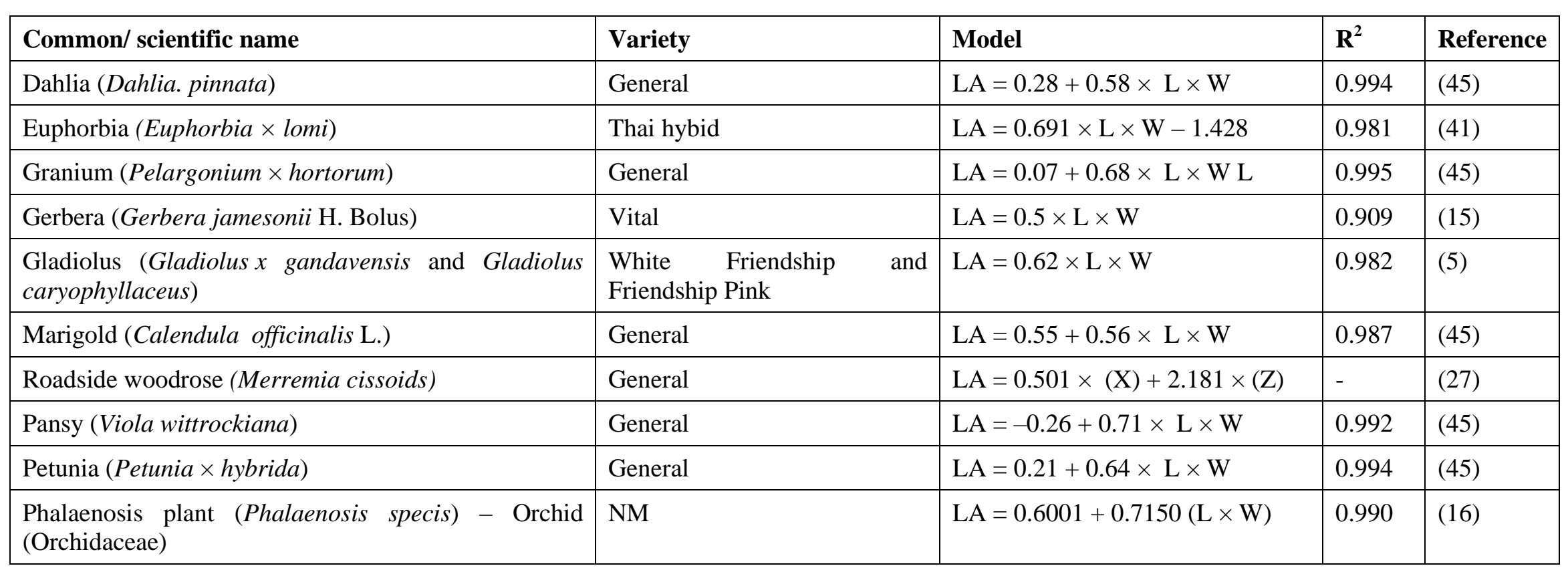


IRA-International Journal of Applied Sciences

\begin{tabular}{|c|c|c|c|c|}
\hline Rose (Rosa species) & General & $\mathrm{LA}=0.56+0.717 \times \mathrm{L} \times \mathrm{W}$ & 0.991 & $(82,40)$ \\
\hline Sweet William (Dianthus barbatus L.) & General & $\mathrm{LA}=-0.06+0.69 \times \mathrm{L} \times \mathrm{W}$ & 0.992 & $(45)$ \\
\hline Sunflower (Helianthus annuus L.) & - & $\begin{array}{l}\mathrm{LA}=-11.2 \times \mathrm{L}+12.3 \times \mathrm{W}+0.66 \\
\times \mathrm{L} \times \mathrm{W}\end{array}$ & 0.94 & (4) \\
\hline Zennia elegans (FB) & Liliput & $\mathrm{LA}=0.0031+0.8003 \times \mathrm{L} \times \mathrm{W}$ & 0.9933 & (71) \\
\hline Zennia elegans (FB) & Thumbelina & $\mathrm{LA}=0.0021+0.8156 \times \mathrm{L} \times \mathrm{W}$ & 0.9925 & (71) \\
\hline Zennia haageana $(\mathrm{FB})$ & Carpet Persa & $\mathrm{LA}=0.0036+0.7719 \times \mathrm{L} \times \mathrm{W}$ & 0.986 & (71) \\
\hline Zennia haageana $(\mathrm{F})$ & Carpet Persa & $\mathrm{LA}=0.0042+0.723 \times \mathrm{L} \times \mathrm{W}$ & 0.9638 & (71) \\
\hline Z. elegans x Z. angustifolia (FB) & Profusion Cherry & $\mathrm{LA}=0.0009+0.7765 \times \mathrm{L} \times \mathrm{W}$ & 0.9885 & $(71)$ \\
\hline Z. elegans $\mathrm{x}$ Z. angustifolia $(\mathrm{F})$ & Profusion Cherry & $\mathrm{LA}=0.0029+0.7899 \times \mathrm{L} \times \mathrm{W}$ & 0.9831 & (71) \\
\hline
\end{tabular}

LA - leaf area; X - L x W of the principal leaflet; Z - L x W of the primary + secondary leaflets; FB - flower bud stage; F - flowering stage

Table 4. Useful leaf area estimation models developed through various studies for medicinal crops

\begin{tabular}{|c|c|c|c|}
\hline Scientific/ local name & Model & $\mathbf{R}^{2}$ & $\begin{array}{l}\text { Referen } \\
\text { ce }\end{array}$ \\
\hline $\begin{array}{ll}\text { Bergenia purpurascens- } & \text { winter-red } \\
\text { bergenia or purple bergenia } & \end{array}$ & $\mathrm{LA}=1.44 \times \mathrm{W}^{1.90}$ & 0.950 & $(98)$ \\
\hline Calamintha nepeta - Calamint & $\mathrm{LA}=-0.23554+[1.067838 \times(\mathrm{L} \times \mathrm{W})]+\left[-0.1526 \times\left(\mathrm{L}^{2} \times \mathrm{W}\right)\right]$ & 0.910 & $(19)$ \\
\hline Coffea Arabica - Coffee & $\mathrm{LA}=0.6626(\mathrm{~L} \times \mathrm{W})^{1.0116}$ & 0.996 & (3) \\
\hline $\begin{array}{l}\text { Laurocerasus officinalis Roem - Cherry } \\
\text { Laurel }\end{array}$ & $\mathrm{LA}=(-55.5877)+(19.98318 \times \mathrm{W})+\left(-0.83723 \times \mathrm{W}^{2}\right)+\left(0.143132 \times \mathrm{L}^{2}\right)$ & 0.950 & $(65)$ \\
\hline Combretum leprosum Mart. - & $\mathrm{A}=0.7103 \times(\mathrm{L} \times \mathrm{W})$ & 0.952 & $(14)$ \\
\hline
\end{tabular}


IRA-International Journal of Applied Sciences

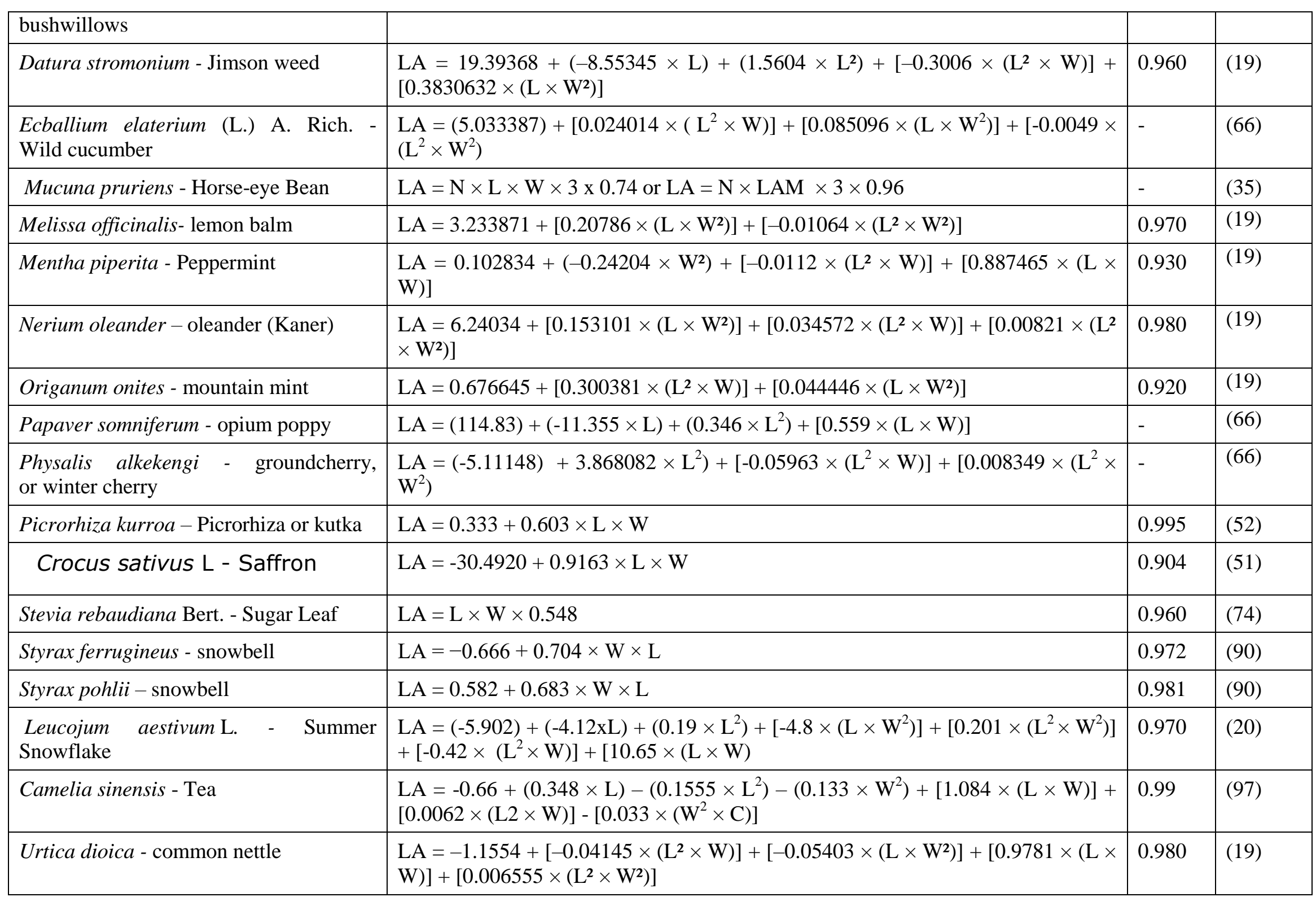


LA - leaf area; $\mathrm{N}$ - total number of leaves plant ${ }^{-1} ; \mathrm{L}, \mathrm{W}$ and LAM are length, width and leaf area meter reading of middle leaflet of 3rd trifoliate leaf from top. 